\title{
The Effect of Rebamipide Administration to the Improvement of Neutrophil-lymphocyte Ratio in COVID-19 Confirmed Patients with ARDS
}

Satriyo Dwi Suryantoro ( $\nabla$ satriyo.dwi.suryantoro@fk.unair.ac.id)

Universitas Airlangga Fakultas Kedokteran https://orcid.org/0000-0002-0522-8659

Anna Surgean Veterini

Universitas Airlangga Fakultas Kedokteran

Bagus Aulia Mahdi

Universitas Airlangga Fakultas Kedokteran

\section{Short Report}

Keywords: COVID-19, Rebamipide, ARDS, health, adjunct therapy

Posted Date: August 6th, 2021

DOI: https://doi.org/10.21203/rs.3.rs-762991/v1

License: @ (i) This work is licensed under a Creative Commons Attribution 4.0 International License. Read Full License 


\section{Abstract}

Rebamipide has a noteworthy potential as an adjunct therapy of coronavirus disease (COVID-19) which may act as an antiIL8. There have been no yet previous studies declared worldwide examining the use of it. We conducted a study of Rebamipide through the secondary data obtained from the medical record then analyzed the neutrophile, lymphocytes, and neutrophillymphocyte ratio of patients. Our data exhibited improvements in the laboratory outcomes, revealing decreased neutrophils, increased lymphocytes, also increased neutrophil-lymphocyte rations, observed in COVID-19 patients experiencing acute respiratory distress syndrome (ARDS).

\section{Main Text}

ARDS is the leading cause of death in COVID-19 patients due to cytokine storms and uncontrolled systemic inflammatory response. ${ }^{1,2}$ Neutrophils are involved in the pathogenesis of ALI / ARDS, while IL-8 (Interleukin-8) has been identified as the main chemotaxis factor for neutrophils in the lung fluid of patients with ALI / ARDS. ${ }^{3}$ Neutrophil-to-Lymphocyte Ratio (NLR) has been identified as an independent risk factor in COVID-19 patients. NLR can be identified at earlier stage to determine the severity of COVID-19. Patients $\geq 50$ years and an NLR of $\geq 3.13$ indicate severe disease, and they should be admitted to the intensive care room if possible. ${ }^{4}$ Lately, SARS-CoV-2 has also been shown to also infect the gastrointestinal tract based on biopsy results on epithelial cells of the stomach, duodenum, and rectum. ${ }^{5}$

According to our systematic review on Tocilizumab which was more preferred in overcoming the severe hyperinflammation, there has been no sufficient treatment in order to manage the hyperinflammation in COVID-19 patients with moderate illness. ${ }^{6}$ Hence, various treatment modalities are still being developed to reduce the hyperinflammation process in moderate illness caused by COVID-19.

Rebamipide is a mucosal protective agent used for the treatment of gastritis and gastric ulcers. It has recently been reported that Rebamipide also acts as an anti-inflammatory agent in acute and chronic inflammation and has an inhibitory effect on proinflammatory cytokines ${ }^{7}$. Rebamipide is reported to inhibit the infiltration of inflammatory cells, free radical formation, and the production of IL-8 so that it provides a strong anti-inflammatory effect. ${ }^{8,9,10,11}$ In this study, Rebamipide will be added to standard therapy in COVID-19 patients with ARDS and compared to those who didn't receive it to determine whether the administration of Rebamipide therapy can help improve the patient's condition, by seeing its effect on neutrophils and lymphocytes and the improvement of Neutrophil-Lymphoctes Ratio (NLR).

This is an observational analytical study with a retrospective cohort design, involving confirmed 180 COVID-19 patients who were admitted to the Airlangga University Hospital, Surabaya in April-September 2020, men or women aged $\geq 18$ years, received standard therapy modalities, with no enteral absorption disorders and met the ARDS criteria. The medical records were grouped into data on patients who received additional Rebamipid $100 \mathrm{mg}$ every 8 hours via the enteral route in addition to the standard therapy modality, as well as data on patients who did not receive Rebamipid. Other data obtained were the neutrophil count, lymphocyte count, and Neutrophil-Lymphocyte Ratio. Data analysis was performed after 2 serial evaluations of complete blood counts at day 3 and 6 after baseline blood tests.

Comparison of median neutrophil, lymphocyte, and NLR values in the Rebamipid and non-Rebamipide groups showed higher neutrophil values, lower lymphocytes, and higher NLRs in the Rebamipide group. However, from the analysis using the Wilcoxon test in evaluating laboratory improvements, in the form of a decrease in neutrophils, an increase in lymphocytes, and an improvement in NLR, the group given Rebamipid tended to improve the values of these three parameters both on the third and sixth day in COVID-19 patients who had ARDS. Statistically, the improvement was significant in moderate and severe ARDS cases in the Rebamipid group. Meanwhile, in the group not given Rebamipide, the improvement in neutrophil, lymphocyte, and NLR values showed results that were mostly not statistically significant.

Table 1. Neutrophill, lymphocyte and Neutrophill-Lymphocyte ratio monitoring between Rebamipide group and non Rebamipide group in ARDS COVID-19 patient. 


\begin{tabular}{|c|c|c|c|c|c|c|c|c|c|c|}
\hline ARDS & Rebamipide & $\begin{array}{l}\text { Lab } \\
\text { (median) }\end{array}$ & Day0 & Day3 & Day6 & $\begin{array}{l}\text { Lab } \\
\text { Improvement }\end{array}$ & Day 0-3 & pValue & $\begin{array}{l}\text { Day } \\
3-6\end{array}$ & pValue \\
\hline \multirow[t]{6}{*}{$\begin{array}{l}\text { Mild } \\
(n=7)\end{array}$} & \multirow[t]{3}{*}{ Yes $(n=3)$} & $\mathrm{Neu}$ & 88,8 & 87,3 & 90,2 & $\begin{array}{l}\text { Neu } \\
\text { decrease (\%) }\end{array}$ & 33,33 & $>0,05$ & 33,33 & $>0,05$ \\
\hline & & Lymph & 6,3 & 7 & 2,7 & $\begin{array}{l}\text { Lymph } \\
\text { increase (\%) }\end{array}$ & 33,33 & $>0,05$ & 66,67 & $>0,05$ \\
\hline & & NLR & 14 & 12 & 24,3 & $\begin{array}{l}\text { NLR } \\
\text { improvement } \\
(\%)\end{array}$ & 33,33 & $>0,05$ & 66,67 & $>0,05$ \\
\hline & \multirow[t]{3}{*}{ No $(n=4)$} & Neu & 71,25 & 68,2 & 76,3 & $\begin{array}{l}\text { Neu } \\
\text { decrease (\%) }\end{array}$ & 25 & 0,273 & 0 & 0,197 \\
\hline & & Lymph & 16,75 & 16,75 & 11,5 & $\begin{array}{l}\text { Lymph } \\
\text { increase (\%) }\end{array}$ & 25 & 0,18 & 50 & 0,655 \\
\hline & & NLR & 4,5 & 5 & 6,82 & $\begin{array}{l}\text { NLR } \\
\text { improvement } \\
(\%)\end{array}$ & 25 & 0,144 & 0 & 0,18 \\
\hline \multirow[t]{6}{*}{$\begin{array}{l}\text { Moderate } \\
(n=58)\end{array}$} & \multirow[t]{3}{*}{ Yes $(n=22)$} & $\mathrm{Neu}$ & 85,9 & 88 & 85,45 & $\begin{array}{l}\text { Neu } \\
\text { decrease (\%) }\end{array}$ & 27,27 & 0,019 & 50 & 0,245 \\
\hline & & Lymph & 9,15 & 7,15 & 9,55 & $\begin{array}{l}\text { Lymph } \\
\text { increase (\%) }\end{array}$ & 13,64 & 0,003 & 57,14 & 0,079 \\
\hline & & NLR & 9 & 12,7 & 8,91 & $\begin{array}{l}\text { NLR } \\
\text { improvement } \\
(\%)\end{array}$ & 13,64 & 0,004 & 64,29 & 0,03 \\
\hline & \multirow[t]{3}{*}{ No $(n=36)$} & $\mathrm{Neu}$ & 78,8 & 81,5 & 76,4 & $\begin{array}{l}\text { Neu } \\
\text { decrease (\%) }\end{array}$ & 36,11 & 0,611 & 65 & 0,048 \\
\hline & & Lymph & 13,5 & 12,7 & 12,2 & $\begin{array}{l}\text { Lymph } \\
\text { increase (\%) }\end{array}$ & 44,44 & 0,326 & 65 & 0,048 \\
\hline & & NLR & 6 & 6,9 & 6,26 & $\begin{array}{l}\text { NLR } \\
\text { improvement } \\
(\%)\end{array}$ & 27,78 & 0,075 & 60 & 0,031 \\
\hline \multirow[t]{6}{*}{$\begin{array}{l}\text { Severe } \\
(n=115)\end{array}$} & \multirow[t]{3}{*}{ Yes $(n=54)$} & $\mathrm{Neu}$ & 87,3 & 89,1 & 89,6 & $\begin{array}{l}\text { Neu } \\
\text { decrease (\%) }\end{array}$ & 39,62 & 0,15 & 27,5 & 0,116 \\
\hline & & Lymph & 6,3 & 4,8 & 3,9 & $\begin{array}{l}\text { Lymph } \\
\text { increase (\%) }\end{array}$ & 28,30 & 0,003 & 35 & 0,152 \\
\hline & & NLR & 14 & 18 & 23 & $\begin{array}{l}\text { NLR } \\
\text { improvement } \\
(\%)\end{array}$ & 33,96 & 0,026 & 35 & 0,046 \\
\hline & \multirow[t]{3}{*}{ No $(n=61)$} & $\mathrm{Neu}$ & 85 & 85,6 & 87,2 & $\begin{array}{l}\text { Neu } \\
\text { decrease (\%) }\end{array}$ & 40,98361 & 0,328 & 44,44 & 0,285 \\
\hline & & Lymph & 8,8 & 7,5 & 6,5 & $\begin{array}{l}\text { Lymph } \\
\text { increase (\%) }\end{array}$ & 32,78689 & 0,052 & 50 & 0,577 \\
\hline & & NLR & 9,3 & 12 & 14 & $\begin{array}{l}\text { NLR } \\
\text { improvement } \\
(\%)\end{array}$ & 29,5082 & 0,001 & 50 & 0,677 \\
\hline
\end{tabular}

Neu = Neutrophill; Lymph : Lymphocyte; NLR : Neutrophill-Lymphocyte Ratio

Rebamipide administration to patients with ARDS likely gives favorable results. This is concluded from the decrease in the number of neutrophil, increase in the number of lymphocytes and a significant improvement in the NLR value on the 3rd and 
the 6th day after Rebamipid administration. This treatment is likely to be an adequate adjunctive therapy in the management of COVID-19. The results of this study can be used as a reference for further research.

\section{Declarations}

Ethics approval : The research ethics committee Universitas Airlangga Hospital (No: 179/KEP/2020). the consent to participate is not applicable since our data is obtained from the med record (secondary data)

Consent for publication : Not applicable;

Availability of data and material : The datasets generated during and/or analysed during the current study are not publicly available due to the ongoing further research and a matter of hospital confidentiality but are available from the corresponding author on reasonable request.

Competing interests : The authors have no relevant conflict of interest

Funding : The authors have no relevant financial disclosure

Authors' contributions : Suryantoro SD : Conceptualization, Formal Analysis, Investigation, Methodology, Software, Supervision, Validation, Writing - Original Draft Preparation, Writing - Review \& Editing; Veterini AS : Conceptualization, Formal Analysis, Investigation, Methodology, Software, Supervision, Validation, Writing - Original Draft Preparation, Writing - Review \& Editing;

Mahdi BA : Conceptualization, Data Curation Formal Analysis, Investigation, Methodology, Project Administration,Resources, Software, Validation, Writing - Original Draft Preparation;

Acknowledgements : We would like to thanks Prof. Dr. Nasronudin dr, Sp. PD KPTI for supporting this research.

\section{References}

1. Huang, C., Wang, Y., Li, X., Ren, L., Zhao, J., Hu, Y., Zhang, L., Fan, G., Xu, J., Gu, X., Cheng, Z., Yu, T., Xia, J., Wei, Y., Wu, W., Xie, X., Yin, W., Li, H., Liu, M., Xiao, Y., Gao, H., Guo, L., Xie, J., Wang, G., Jiang, R., Gao, Z., Jin, Q., Wang, J. and Cao, B. (2020) 'Clinical features of patients infected with 2019 novel coronavirus in Wuhan, China', The Lancet, 395(10223), pp. 497-506. doi: 10.1016/S0140-6736(20)30183-5.

2. Li, X., Geng, M., Peng, Y., Meng, L. and Lu, S. (2020) 'Molecular immune pathogenesis and diagnosis of COVID-19', Journal of Pharmaceutical Analysis, 10(2), pp. 102-108. doi: 10.1016/j.jpha.2020.03.001.

3. Fudala, R., Krupa, A., Stankowska, D., Allen, T. C. and Kurdowska, A. K. (2008) 'Anti-interleukin-8 autoantibody:interleukin-8 immune complexes in acute lung injury/acute respiratory distress syndrome', Clinical Science, 114(6), pp. 403-412. doi: 10.1042/CS20070272.

4. Liu, J., Liu, Y., Xiang, P., Pu, L., Xiong, H., Li, C., Zhang, M., Tan, J., Xu, Y., Song, R., Song, M., Wang, L., Zhang, W., Han, B., Yang, L., Wang, Xiaojing, Zhou, G., Zhang, T., Li, B., Wang, Y., Chen, Z. and Wang, Xianbo (2020) 'Neutrophil-to-Lymphocyte Ratio Predicts Severe Illness Patients with 2019 Novel Coronavirus in the Early Stage', medRxiv, p. 2020.02.10.20021584. doi: 10.1101/2020.02.10.20021584.

5. Xiao, F., Tang, M., Zheng, X., Liu, Y., Li, X. and Shan, H. (2020) 'Evidence for Gastrointestinal Infection of SARS-CoV-2', Gastroenterology. Elsevier, 158(6), pp. 1831-1833.e3. doi: 10.1053/j.gastro.2020.02.055.

6. Nugroho CW, Suryantoro SD, Yuliasih Y et al. Optimal use of tocilizumab for severe and critical COVID-19: a systematic review and meta-analysis [version 1; peer review: 1 approved]. F1000Research 2021, 10:73 
(https://doi.org/10.12688/f1000research.45046.1)

7. McCarthy, J., O’Mahony, L., O’Callaghan, L., Sheil, B., Vaughan, E. E., Fitzsimons, N., Fitzgibbon, J., O’Sullivan, G. C., Kiely, B., Collins, J. K. and Shanahan, F. (2003) 'Double blind, placebo controlled trial of two probiotic strains in interleukin 10 knockout mice and mechanistic link with cytokine balance.', Gut, 52(7), pp. 975-80. doi: 10.1136/gut.52.7.975.

8. Watanabe, S., Wang, X. E., Hirose, M., Osada, T., Tanaka, H. and Sato, N. (1998) 'Rebamipide prevented delay of wound repair induced by hydrogen peroxide and suppressed apoptosis of gastric epithelial cells in vitro.', Digestive diseases and sciences, 43(9 Suppl), pp. 107S-112S. Available at: http://www.ncbi.nlm.nih.gov/pubmed/9753235.

9. Kim, H., Seo, J. Y. and Kim, K. H. (2000) 'Inhibition of lipid peroxidation, NF-kappaB activation and IL-8 production by rebamipide in Helicobacter pylori-stimulated gastric epithelial cells.', Digestive diseases and sciences, 45(3), pp. 621-8. doi: 10.1023/a:1005474013988.

10. Hiratsuka, T., Futagami, S., Shindo, T., Hamamoto, T., Ueki, N., Suzuki, K., Shinji, Y., Kusunoki, M., Shinoki, K., Wada, K., Miyake, K., Gudis, K., Tsukui, T. and Sakamoto, C. (2005) 'Rebamipide Reduces Indomethacin-Induced Gastric Injury in Mice via Down-Regulation of ICAM-1 Expression', Digestive Diseases and Sciences, 50(S1), pp. S84-S89. doi: 10.1007/s10620-005-2811-6.

11. Sakurai, K., Osaka, T. and Yamasaki, K. (2005) 'Rebamipide Reduces Recurrence of Experimental Gastric Ulcers: Role of Free Radicals and Neutrophils', Digestive Diseases and Sciences, 50(S1), pp. S90-S96. doi: 10.1007/s10620-005-2812-5.

\section{Figures}

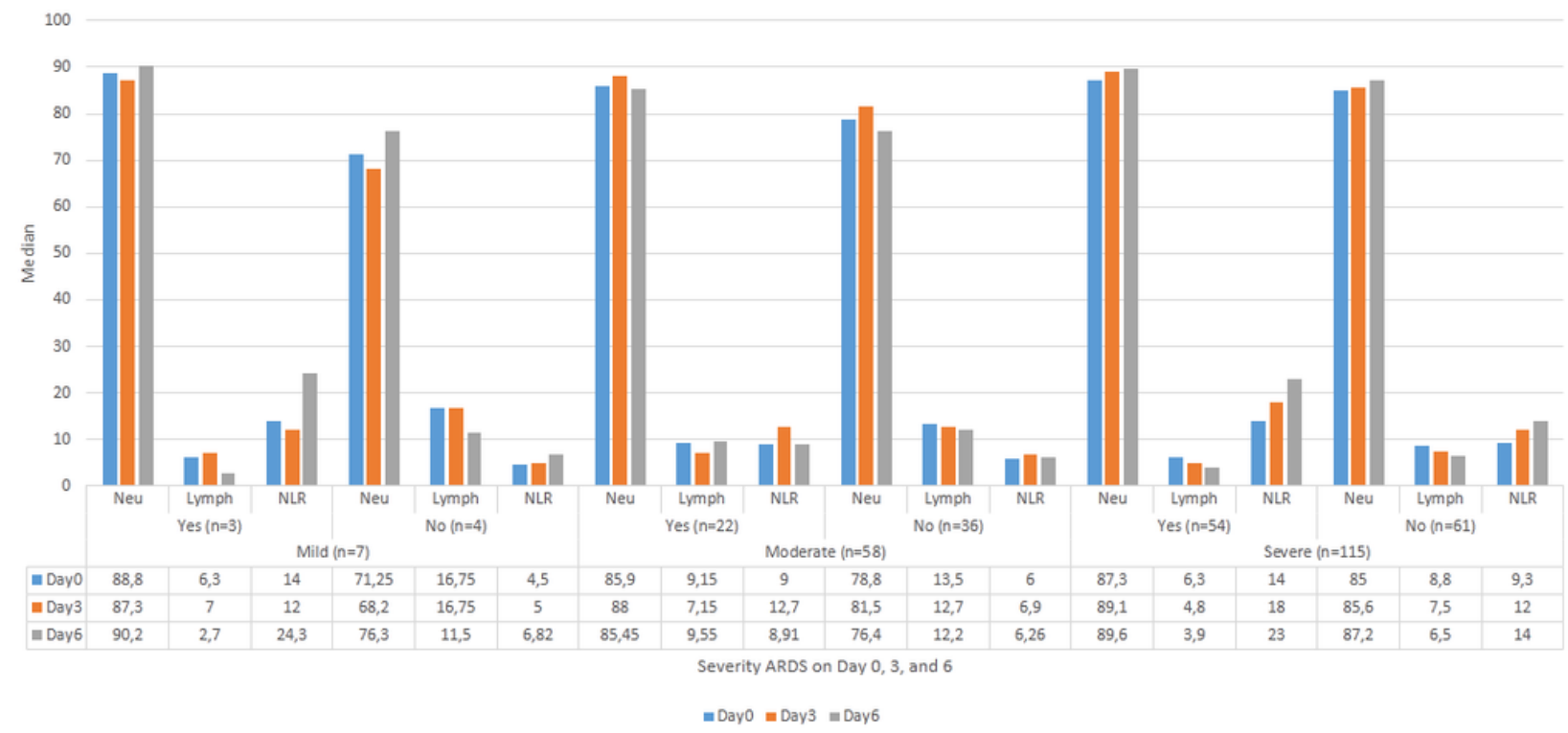

Neu = Neutrophill; Lymph : Lymphocyte; NLR : Neutrophill-Lymphocyte Ratio

\section{Figure 1}

Comparison of neutrophill, lymphocyte, and neutrophill-lymphocyte ratio between rebamipide group and non rebamipide group in ARDS COVID-19 patients. 